DOI: 10.35340/2308-104X.2020.86-1-24

\section{ЗАВДАННЯ ІМПЛЕМЕНТАЦЇ̈ \\ ЗАРУБІЖНОГО ДОСВІДУ \\ ПУБЛІЧНОГО УПРАВЛІННЯ РОЗВИТКОМ ПРИМОРСЬКИХ ТЕРИТОРІЙ}

\author{
ГОЛТВЕНКО О. В., \\ здобувач, \\ Донецький державний \\ університет управління
}

\section{THE TASKS FOR IMPLEMENTING THE INTERNATIONAL PRACTICES OF THE PUBLIC GOVERNMENT OF COASTAL TERRITORIES DEVELOPMENT}

DEVELOPMENT

\author{
GOLTVENKO O., \\ PhD student, \\ Donetsk State University of \\ Management
}

У статті узагальнено знання щзодо приморських територій АзовоЧорноморського басейну Украӥни. Узагальнені юрисдикиіі підпорядкування та доведено відсутність інтегрованого управління прибережною зоною. В результаті проведеного аналізу поставлені завдання імплементачії зарубіжного досвіду публічного управління розвитком приморських територій.

Ключові слова: розвиток, приморські території, публічне управління, досвід, результативність, соціальний, економічний, екологічний, комунікаиія, менеджмент

В статье обобщены знания о приморских территориях АзовоЧерноморского бассейна Украиньл. Обобщены юрисдикиии подчинения и доказано отсутствие интегрированного управления прибрежной зоной. В результате проведенного анализа поставлень задачи имплементации зарубежного опыта публичного управления развитием приморских территорий.

Ключевые слова: развитие, приморские территории, публичное управление, опыт, результативность, сочииальный, экономический, экологический, коммуникация, менеджмент

The article summarizes the knowledge about the coastal territories of the Azov-Black Sea basin of Ukraine. The research shows the jurisdictions of subordination and evinces the lack of integrated coastal zone management. As a result of the conducted analysis have been set the tasks of implementation of foreign experience of public management of coastal territories.

Keywords: development, coastal territories, coastal governance, experience, efficiency, social, economical, ecological, communication, management

Постановка проблеми. Приморські території являють собою відновлювані цінні середовища для існування численних рослин та видів тварин. На жаль, зростання населення, а також економічний розвиток за рахунок надмірної експлуатації природних ресурсів спричинили появу 
спектру проблем екологічного характеру в тому числі. Вирішення завдань соціо-еколого-економічного розвитку приморських територій покладено на державні інституції за механізмами, які втрачають актуальність через брак інноваційних підходів, невідповідність міжнародним тенденціям до управління береговими територіями морських держав тощо.

Аналіз останніх досліджень $i$ публікачій. Поширення набули дослідження приморських територій як рекреаційних. Оцінці рекреаційної місткості і природно-рекреаційного потенціалу територій присвячені численні роботи С. А. Генсирука, Л. С. Гриніва, М. І. Долишного, В. С. Кравцива, М. С. Нижник, М. С. Нудельмана і багатьох інших.

Дослідженню еколого-економічних проблем раціонального використання приморських територій присвячені труди А. М. Вишнякової. Певний погляд на державну стратегію управління процесами природокористування приморських регіонів зробив В. І. Демченко, О. П. Павленко. В той же час аналізу бракує глибинності дослідження ролі публічного управління в розвитку приморських територій та відсутність цілеспрямованих дій органів державної влади щодо імплементації успішних закордонних практик розвитку приморських територій, а включення України до переліку досліджуваних щодо менеджменту приморських територій.

Метою статті є формулювання завдань імплементації зарубіжного досвіду публічного управління розвитком приморських територій.

Виклад основного матеріалу. Приморські території - це складова територіальних ресурсів, які можуть бути виділені з ряду інших регіонів на основі аналізу фізико-географічних факторів і ознак, властивих формам освоєння таких територій і спрямованості їх економічного розвитку та екологічними й соціальними наслідками. Приморськими вважаються адміністративно-територіальні одиниці, які безпосередньо або опосередковано (через акваторії лиманів) прилягають до узбережжя Чорного та Азовського морів [1]. При визначенні кордонів приморських територій, спираємось на Стратегію інтегрованого управління кордонами [1], де вказано, що загальна протяжність морської ділянки державного кордону становить 731 морську милю, з яких 570 миль по Чорному морю, 135 миль - по Азовському, 26 миль - по Керченській протоці. Протяжність державного кордону по р. Дунай - 98 миль. Площа виключної (морської) економічної зони становить майже 21,2 тис. квадратних миль [1]. 
В умовах Азово-Чорноморського басейну варто враховувати фактори, що впливають на глибину освоєння територій, що діють порізному в районах узбережжя:

а) кліматичну характеристику району, яка дає можливість виявити найбільш коштовну в курортологічному відношенні територію чи курортну зону (глибина їі може коливатися від 2 до 10 км);

б) гірський рельєф, який обмежує поширення господарських зв'язків узбережжя 3 глибинними територіями (наприклад, на південному узбережжі від 1,5 до 3 км);

в) особливості прибережної смуги, зокрема, наявність солоних лиманів, що розширюють приморську територію на 20-30 км, гирла великих річок, що збільшують приморські території на 50-100 км і більше, які використовують як джерела водопостачання і дешеві транспортні шляхи;

г) сформовану систему населених місць на узбережжі і територіях, що примикають, наявність великих і найбільших міст (Одеса, Маріуполь $i$ ін.);

д) існуючий адміністративний розподіл - межі областей, сільських районів, приміських зон найбільших міст [2].

Прибережна зона в Україні знаходиться під юрисдикцією влади на чотирьох рівнях: національному, регіональному, муніципальному та місцевому. В Україні немає спеціальних державних органів, відповідальних за інтегроване управління прибережною зоною (Integrated Management of Coastal Territories). Узагальнено, деякі з функції в цій галузі виконують: Міністерство інфраструктури; Міністерство екології та природних ресурсів України; Міністерство розвитку громад та територій. Активно діє Державна служба морського та річкового транспорту України, Державна інспекція охорони Чорного та Азовського морів, яка займається прибережними районами. Додатковими установами є Державні агентства 3 питань екології та природних ресурсів, які $є$ в кожному адміністративному регіоні (області). Остання організація відповідає за проведення державної екологічної політики в певних прибережних районах.

Система державного управління розвитком прибережної зони включає: об'єкт управління (землі та об'єкти загальнодержавної, приватної, комунальної власності та власності місцевих громад); суб'єкти управління (органи законодавчої, виконавчої, судової влади та місцевого самоврядування, установи, організації та підприємства); нормативноправову базу (закони, законодавчі акти та нормативні документи, що 
регулюють правовідносини, які склалися при управлінні розвитком та використанням територій); ресурсне забезпечення (людські, майнові, фінансові та інші ресурси, необхідні для розвитку та використання територій). Можна виділити певні етапи розвитку практики управління прибережними зонами в Україні як об'єкта наукових досліджень (з початку 1990-х років), об'єкта національної політики (з другої половини 1990-х років) та об'єкта інтегрованого управління (з кінця 1990-х років). Саме на такому підході побудовані проєкти Концепції національної політики i стратегії інтегрованого управління прибережною смугою Чорного i Азовського морів України (1997), Концепції закону України «Про природокористування у прибережній смузі Чорного і Азовського морів», окремі положення Загальнодержавної програми охорони та відтворення довкілля Азовського і Чорного морів (2001) та проєкту Закону України «Про прибережну смугу морів» (2004). Це основні положення законодавчої бази, яка має слугувати основою системи державного управління розвитком прибережних зон [3].

Однак, дослідження закордонного досвіду та науки публічного управління дозволяють стверджувати, що результативність розвитку приморських територій забезпечується за рахунок координаційних дій 3 ефективності комунікативного зв'язку 3 всіма зацікавленими стейкхолдерами та органами місцевого самоврядування, налагодження взаємозв'язку з міністерствами та відомствами, що здійснюють регулюючу функцію в рамках приморських територій, а також гармонізації стосунків 3 міжнародною спільнотою та імплементація світового досвіду щодо забезпечення публічного управління розвитком приморських територій.

Так, дискусії щодо більш інтегрованого управління приморськими територіями набувають значущості в політичному дискурсі [4]. Поки значно більше знань та досвіду в галузі управління соціо-екологоекономічними системами накопичувалось протягом століть. Зазначимо, що вплив антропогенного походження на морські та прибережні системи відзначаємо як соціальну складову системи, яка в свою чергу може виступати керуючою та керованою підсистемою одночасно, тому потребує більш виважених регуляторних інструментів. Останні, в свою чергу, сприяють інтегрованим формам багатоскалярного та міжгалузевого управління в екологічно різноманітних приморських територіях. Тому, щоб захистити та досягти збалансованого використання ресурсів приморських територій, моря та океанів, представники органів публічного управління та інші зацікавлені стейкхолдери стикаються 3 двома 
характерними проблемами на глобальному рівні. По-перше, ослаблення стійкості природних екосистем у поєднанні 3 антропогенними змінами клімату та важкістю узгодження ряду перехресних місцевих, регіональних та глобальних проблем, часто пов’язаних з розвитком систем виробництва та споживання, збільшенням кількості населення світу поряд із кінцевістю планетарних ресурсів (ООН передбачає 9 мільярдів населення у 2050 році [6]). По-друге, глибоководний видобуток корисних копалин.

На регіональному рівні, наприклад, Свропа демонструє перехід до блакитної економіки, одночасно захищаючи природні ресурси, що призвело до активізації контекстного підходу до управління океанами та приморськими територіями (Joint Communication of EU Commission, Council \& Parliament 2016/49, Commission Implementation Decision 2014/1447; COM, 2012/494 final; COM, 2014/86 final). В результаті, Європейська Комісія розпочала консультативний процес, щоб розглянути, як найкраще посилити узгодженість та всебічність політики щодо вдосконалення своєї міжнародної системи морського управління (Європейська комісія, 2015).

До наднаціонального діалогу (ABNJ) щодо управління приморськими територіями керівництва країн в рамках конференції ООН про зміну клімату (UNFCCC) підштовхнули і націоналістичний популізм у багатьох частинах Європи та США, і об'єми видобутку та споживання блакитного палива, а також проблеми дна океанів. Координація морської та наземної політик та інтеграція процесів стали доки невирішеним завданням для керуючих систем як на глобальному, так і на місцевому рівні, а також економічних наслідків та соціальних перетворень.

Отже, публічне управління приморськими територіями є складовою загальнодержавного управління та включає попри все спроможність уряду ефективно формувати та реалізовувати обгрунтовану політику, а також повагу громадян та держави до інституцій, що регулюють економічну та соціальну взаємодію між ними. Однак, за загальним індексом державного управління (Worldwide Governance Indicators), оцінка дій уряду протягом останніх 5 років коливається у від’ємних показниках ефективності (рис. 1). За даними [7] ефективність уряду фіксує уявлення про якість державних послуг, якість державної служби та ступінь иї незалежності від політичного тиску, якість формування та реалізації політики та достовірність прихильності уряду до такої політики. Маркер дає оцінку країни за сукупним показником, в одиницях стандартного нормального розподілу, тобто коливається приблизно від $-2,5$ до 2,5. 


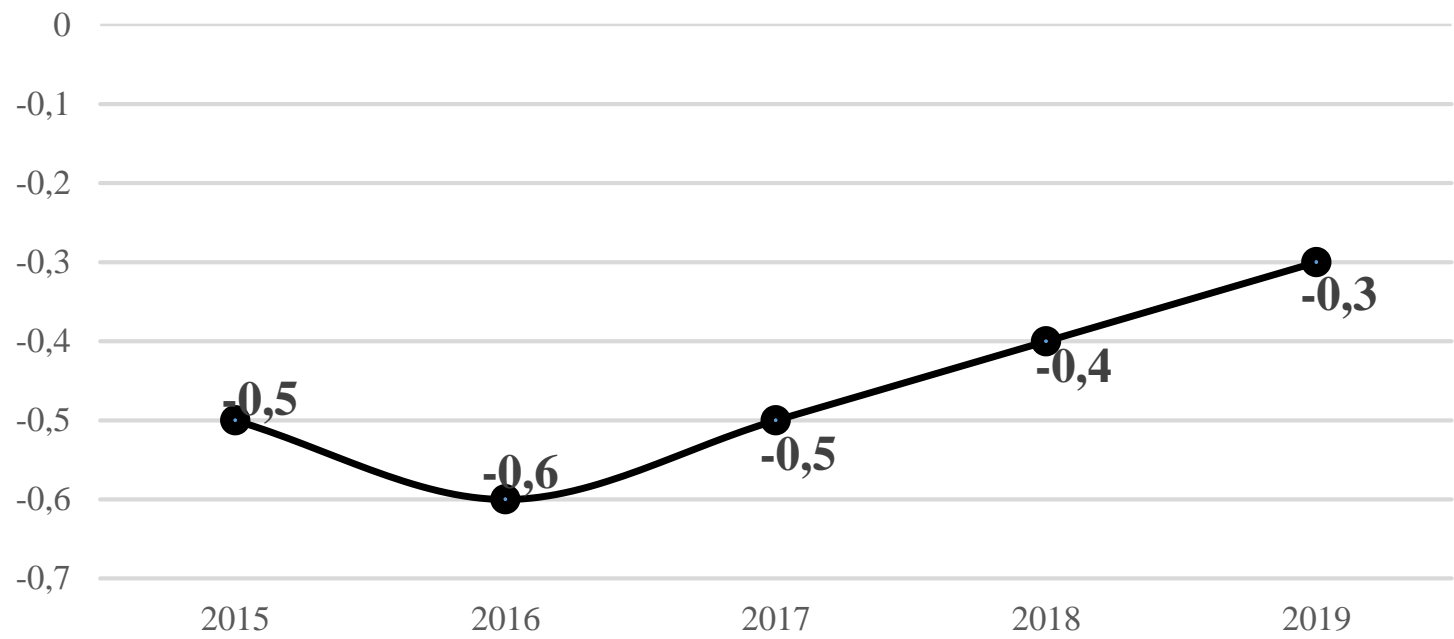

*Складено за даними worldbank.org [7]

Рис. 1. Оцінка ефективності уряду України 2015-2019 pp за даними Світового банку

Свідомо, що дані показники сформовані під впливом багатьох факторів дестабілізації як на національному, так і на глобальному рівні. Однак, інтеграції України в міжнародну спільноту морських держав, перш за все, сприятиме зважена політика реалізації морського потенціалу, який нерозривно йде 3 удосконаленням соціо-еколого-економічної системи приморських територій. Так, аналіз світового досвіду дозволяє рекомендувати до виконання наступного задання імплементації зарубіжного досвіду публічного управління розвитком приморських територій:

1. Розроблення та реалізація національної стратегії раціонального використання та захисту приморських територій Азово-Чорноморського узбережжя, морських заток і лиманів, а також кооперації з прилеглою морською акваторією, що дозволить раціоналізувати та підвищити результативність системи управління та відновлення прибережних та морських екосистем.

2. Розроблення та імплементація механізмів інноваційного розвитку приморських територій із залученням науковців та лідерів громадської думки до публічного обговорення та опрацювання стратегій розвитку територій за напрямами, наприклад, туризм, креативні індустрії, вільні економічні зони, в т.ч. розвиток марикультури, транскордонне співробітництво, тощо. 
3. Підтримка інфраструктурних проєктів (будівництво, транспортна логістика тощо), які сприятимуть громадській згуртованості, підвищенню рівня грамотності та комунікації, прискоренню економічного зростання при невиснажливому використанні природних ресурсів.

4. Створення координаційно-комунікативних центрів (Маріуполь, Запоріжжя, Одеса, Херсон, Миколаїв), з метою забезпечення ефективності комунікативного зв'язку 3 всіма зацікавленими стейкхолдерами та органами місцевого самоврядування, налагодження взаємозв'язку 3 міністерствами та відомствами, що здійснюють регулюючу функцію в рамках приморських територій, а також гармонізації стосунків 3 міжнародною спільнотою та імплементації світового досвіду щодо забезпечення державного управління розвитком приморських територій.

5. Інвентаризація об’єктів природно-заповідного фонду місцевого значення, розташованих на приморських територіях; удосконалення правил забудови з урахуванням екологічних стандартів та збереження екосистеми територій.

6. Побудова сценарію подальшого інноваційного розвитку приморських територій за умов співпраці між закладами вищої освіти, бізнесу та органами публічного управління з територіальними громадами у сфері збереження навколишнього природного середовища та розвитку регіональної економіки, пов'язаної 3 використанням морської та прибережної зон, а також виявлення актуального для громади вектору розвитку приморської території.

Висновки та перспективи подальших досліджень. Сформульовані задання імплементації зарубіжного досвіду публічного управління розвитком приморських територій дозволять координувати публічне управління в аспектах соціо-еколого-економічного розвитку приморських територій, досягнення ефективності використання державних ресурсів у територіальних громадах в інтересах людини, використання природних ресурсів відповідно до світових вимог й збереження екосистеми для майбутніх поколінь навіть на глобальному рівні. Також, виконання сформульованих завдань дозволять наблизитись до світових стандартів інтегрального управління прибережною зоною, що в свою чергу піднесе позиції України як морської держави на регіональному Європейському рівні.

Розвиток приморських територій в соціо-еколого-економічному аспекті має й «сліпі плями», адже передбачає посилання на думку громади, яка не завжди представляє об'єктивний погляд на екоскладову, наприклад. 
Тому, приморські території, як агрегації виробництв, освітніх просторів, заповідних зон та прикордонного співробітництва, повинні виховувати соціальну складність громади. Вона дозволяе прояву різних реакцій на зміни навколишнього середовища, адаптацію до більшої кількості аспектів, а аспект когнітивної складності дає можливість розглядати різні варіанти як сценарії, перш ніж вибрати курс - запобігти виникненню ризику. Подальшого дослідження потребує гіпотеза щодо соціальної складності громад приморських територій та їх включення до процесів публічного управління. Адже, складність і адаптація мають свою ціну (економічний аспект). Нівеляція специфіки громади приморської території до загальнонаціонального рівня має призвести до соціальних флуктуацій, дисбалансу розвитку соціо-еколого-економічної системи вже в умовах децентралізації. Навіть теза про створення комунікативнокоординаційного центру в приморських територіях доводить наявність специфіки приморських територій, що втілюють нові поєднання соціальних та екологічних систем, нових поєднань між рівнями управління, що зволить органам місцевого самоврядування приймати рішення відповідно до запиту громади та індексу управління прибережною зоною.

\section{Jimepamypa:}

1. Щодо шляхів покращення соціально-економічного стану депресивних приморських територій України: Аналітична записка URL: http://old2.niss.gov.ua/articles/1424/.

2. Вишнякова А. М. Еколого-економічні проблеми раціонального використання територій (на прикладі приморських регіонів): автореф. дис. на здобуття наук. ступеня канд.економ.наук.: 08.08.01. Київ, 2004. 230 с.

3. Павленко О. П. Основні засади державного управління розвитком прибережних зон. Вісник Донецького державного університету управління «Менеджер». 2015. №1 (69). С. 96-100.

4. Worldwide Governance Indicator: Ukraine. URL: https://databank. worldbank.org/source/worldwide-governance-indicators.

5. Pittman J., Armitage D. Governance across the land-sea interface: a systematic review Environ. Sci. Policy. 2016. 64. P. 9-17.

6. Growing at a slower pace, world population is expected to reach 9.7 billion in 2050 and could peak at nearly 11 billion around 2100 URL: https://www.un.org/development/desa/en/news/population/world-populationprospects-2019.html. 


\section{References:}

1. Schodo shlyachiv pokraschennya socialno-economichnogo stanu depresivnih primorskih territoriy Ukraini: analitichna zapiska. URL: http://old2.niss.gov.ua/articles/1424/.

2. Vishnyakova A. M. Ecologo-economichni problem racionalnogo vikoristannya teritoriy (na prikladi primorskih regioniv): avtoreferat. dis. na zdobuttya nauk.stupenya candidata econom.nauk.: 08.08.01. Kiyv, 2004. 230 p.

3. Pavlenko O.P. Osnovni zasadi derzhavnogo upravlinnya rozvitkom pribreznih zone. Visnik Donetskogo derzhavnogo universitetu upravlinnya «Menedger». 2015. №1 (69). C. 96-100.

4. Worldwide Governance Indicator: Ukraine. URL: https://databank.worldbank.org/source/worldwide-governance-indicators.

5. Pittman J., Armitage D. Governance across the land-sea interface: a systematic review Environ. Sci. Policy. 2016. 64. P. 9-17.

6. Growing at a slower pace, world population is expected to reach 9.7 billion in 2050 and could peak at nearly 11 billion around 2100 URL: https://www.un.org/development/desa/en/news/population/world-populationprospects-2019.html.

The article summarizes the knowledge about the coastal areas of the Azov-Black Sea basin of Ukraine. The formulated tasks of implementation of foreign experience of public management of coastal territories will allow to coordinate public management in socio-ecologo-economical development aspect of coastal territories, the achievement of efficiency of state resources use in territorial communities according personal interests, the use of natural resources in accordance with world requirements and preservation of the ecosystem for future generations, even at the global level. Item, the accomplishment of formulated tasks of implementation of foreign experience of public management of coastal territories development will allow to approach the world standards of integrated coastal zone management, which in turn will raise the position of Ukraine as a maritime state at the regional European level.

The development of coastal areas in socio-ecologo-economical aspect also has «blind spots», as it involves a reference to the opinion of the community, which does not always represent an objective view of the eco-component, for example. Therefore, coastal areas, as aggregations of industries, educational spaces, nature parks and reservation areas and cross-border cooperation, must cultivate the social complexity of the community. Societal complexity allows for 
more different responses to environmental change, adaptations to more aspects of the environment, and the aspect of cognitive complexity renders it possible to entertain different options as scenarios, before choosing a course. It helps to prevent a risk. Further research is needed on the hypothesis of the social complexity of communities in coastal areas and their inclusion in public administration processes. After all, complexity and adaptation have their price (economical aspect). Leveling the specifics of the community of the coastal territory to the national level should lead to social fluctuations, imbalance in the development of the socio-ecologo-economical system already in the conditions of decentralization. Even the thesis of creating a communication and coordination center in coastal areas proves the specifics of coastal areas, embodying new combinations of social and environmental systems, new combinations between levels of government, which will allow local governments to make decisions according to community demand and Coastal Governance Index. 